\title{
Strategi Branding Pelaku Usaha Pariwisata di Masa Pandemi
}

\author{
Chotijah Fanaqi, Resty Mustika Pratiwi, Firmansyah \\ Fakultas Ilmu Komunikasi Universitas Garut \\ chotijah@uniga.ac.id
}

\begin{abstract}
The pandemic condition has made the business world sluggish. As a sector engaged in services, tourism is also affected. This is due to the government's prohibition of opening a business that has the potential to invite large crowds due to the need for physical distancing as an effort to prevent the occurrence of covid 19 transmission. However, since the enactment of the new normal, namely the period of adaptation to new habits, the tourism sector has made improvements. As one of the areas that has good tourism potential in West Java, Garut continues to make efforts to make itself a tourist destination city that is feasible and safe to visit. Besides having sufficient tourism potential, open nature-based tourism makes Garut Regency a magnet for tourists during pandemic. This study aims to determine how the Garut regency branding strategy as a tourist destination and what are the challenges during pandemic. The researcher uses the theory of branding strategy initiated by Kotler (2009) which explains that the branding strategy has three main components, namely; brand positioning, brand personality, and brand identity. The method in this research uses qualitative methods with interview, observation, and documentation techniques in data collection efforts.

Keywords: Branding Strategy, Tourism, Pandemic.

Abstrak- Kondisi pandemic menjadikan dunia usaha menjadi lesu. Sebagai sector yang bergerak di bidang jasa, pariwisata juga turut terkena imbasnya. Hal tersebut karena adanya larangan pemerintah untuk membuka usaha yang berpotensi mengundang kerumunan orang banyak karena perlunya physical distancing sebagai upaya pencegahan terjadinya penularan covid 19. Namun sejak diberlakukannya new normal, yakni masa adaptasi pada kebiasaan baru, sektor pariwisata melakukan pembenahan. Sebagai salah satu daerah yang memiliki potensi wisata yang cukup baik di Jawa Barat, Garut terus melakukan upaya untuk menjadikan dirinya sebagai kota destinasi wisata yang layak dan aman untuk dikunjungi. Disamping memiliki potensi wisata yang memadai, wisata yang berbasis alam terbuka menjadikan kabupaten garut memiliki magnet tersendiri bagi para wistawan di masa pandemi. Penelitian ini bertujuan untuk mengetahui bagaimana strategi branding kabupaten Garut sebagai destinasi wisata serta apa saja tantangannya di masa pandemic. Peneliti menggunakan teori strategi branding yang digagas oleh Kotler (2009) yang memaparkan bahwa strategi branding memiliki tiga komponen utama, yakni; brand positioning, brand personality, dan brand identity. Adapun metode dalam penelitian ini menggunakan metode kualitatif dengan teknik wawancara observasi, dan dokumentasi dalam upaya pengumpulan data. Kata kunci: Strategi Branding, Pariwisata, pandemic.
\end{abstract}

\section{PENDAHULUAN}

Kebijakan desentralisasi di Indonesia telah memberikan legitimasi dan payung hukum kepada setiap daerah untuk merancang dan membuat kebijakan yang sesuai dengan kebutuhannya dalam rangka menggali serta mengembangkan segala potensi yang dimiliki daerah, termasuk diantaranya potensi di bidang pariwisata. Kebijakan desentralisasi tersebut berdasarkan undang-undang No. 22 Tahun 1999 Tentang otonomi daerah. Kebijakan otonomi daerah di Indonesia memberikan hak, wewenang, dan kewajiban bagi setiap daerah untuk membuat aturan dan mengelola sendiri urusan pemerintahan berdasarkan kepentingan masyarakat setempat sesuai dengan peraturan perundang-undangan yang berlaku. Hal ini sebagai upaya untuk mendorong dan memberikan kebebasan kepada pemerintah daerah dalam mengelola dan mengembangkan segala potensi yang dimilikinya. Sektor wisata merupakan salah satu andalan bagi daerah yang dianggap mampu mendatangkan devisa bagi daerah, bahkan juga bagi negara. Pariwisata menjadi sector yang menghasilkan multiplayer effect tidak hanya bagi daerah tapi juga bagi masyarakat setempat dalam menunjang roda perekonomian. Beberapa sektor pariwisata daerah yang cukup popular dan menunjang pendapatan daerah contohnya adalah seperti Bali, Yogyakarta, Lombok, Papua, dan beberapa daerah lainnya di Indonesia.

Sebagai salah satu daerah yang memiliki potensi wisata yang cukup baik di Jawa Barat, Garut terus melakukan upaya untuk menjadikan dirinya sebagai kota destinasi wisata. Hal ini dikarenakan beberapa tahun terakhir, Garut merupakan tempat favorit bagi para wisatawan, baik yang berasal dari dalam kota, luar kota, bahkan mancanegara. Kekayaan dan keindahan alam garut memiliki magnet tersendiri bagi para wistawan. Hal tersebut menjadi alasan mengapa garut menjadi tempat yang disukai untuk melepas penat, jalan-jalan, atau bahkan untuk tujuan bulan madu.

Kondisi alam garut yang tidak biasa menjadikan ciri khas bagi kota garut. Disamping memiliki kawasan cipanas yang terkenal dengan kolam renang air panasnya, garut juga memiliki kawasan selatan yang menghadirkan keindahan laut berikut pantainya yang eksotis. Sejumlah dataran tinggi yang dimiliki oleh 
garut menyimpan potensi yang tak kalah menarik. Beberapa diantaranya seperti air terjun dan kawasan pendakian menjadikan garut menarik untuk dijadikan tempat berkemah dan mendaki.

Kondisi pandemic ditandai dengan menyebarnya covid 19 beberapa bulan belakangan menjadikan dunia usaha, terutama di sector pariwisata menjadi lesu. Hal tersebut karena adanya larangan pemerintah untuk membuka usaha yang berpotensi mengundang atau mendatangkan banyak orang karena perlunya physical distancing sebagai upaya pencegahan terjadinya penularan covid 19. Kebijakan ini tentu sangat berpengaruh tidak hanya pada sector wisata, akan tetapi juga pada sector yang mendukungnya, seperti sektor transportasi (travel), kuliner, hotel, UMKM, dan lain sebagainya.

Sejak diberlakukannya new normal, yakni masa adaptasi pada kenormalan baru, sektor pariwisata juga melakukan pembenahan. Banyak pihak yang menyambut baik kebijakan ini, sebab pariwisata menjadi bagian yang tidak bisa diindahkan dari salah satu kebutuhan manusia yang membutuhkan hiburan dalam rangka upaya menenangkan dan mendatangkan rasa nyaman. Terlebih, kondisi pandemic yang telah menjangkit Indonesia sejak awal tahun 2020 memaksa masyarakat untuk tetap di rumah saja (stay at home).

\section{Tinjauan tentang Branding Pengertian Branding}

Istilah branding menurut Kotler (2009) memiliki pengertian sebagai pemberian simbol, nama, identitas, rancangan, tanda, atau istilah yang digunakan guna mengidentifikasikan sebuah barang atau jasa yang dimilikinya, selain itu branding menjadi pembeda dengan barang atau jasa orang lain.

Menurut American Marketing Assosiation (AMA), branding merupakan sebuah nama, design, simbol, ataupun kombinasi dari diantaranya yang dipakai pertama kali sebagai fungsi identitas barang atau jasa dari pemilik produk atau jasa serta sebagai pembeda dengan produk atau jasa yang dimiliki pesaing. Sedangkan menurut Interbrand, brand merupakan perpaduan atribut tangible dan intangible, yang disimbolkan ke dalam sebuah merek dagang (trademark) tertentu. Brand apabila dimanage dengan baik dapat membawa dampak yang menghasilkan sebuah nilai (Clifton, 2000).

Brand memiliki nilai lebih dari sekedar produk, sebab produk merupakan barang yang diproduksi pabrik, sedangkan brand merupakan sesuatu yang dibeli oleh konsumen (Masruroh, 2018).
Konsumen membeli sebuah barang, bukan hanya butuh terhadap fungsi barang tersebut, akan tetapi lebih dari itu, brand dari barang tersebut memiliki nilai yang membuat konsumen memilih sebuah produk. Sebagai sebuah identitas, Brand juga memiliki benefit yang bisa mendatangkan persepsi yang positif bagi konsumen. Kekuatan branding dianggap memiliki pengaruh yang cukup signifikan sehingga bisa membangun brand awareness yang pada akhirnya meningkatkan nilai jual (Susanto, 2004).

Selain brand, reputasi menjadi bagian penting bagi terbentuknya sebuah brand. Brand dan reputasi memiliki keterkaitan yang saling mempengaruhi satu sama lain. Reputasi menjadi urgent, agar apa yang ditawarkan oleh sebuah brand dapat diterima dengan baik oleh khalayak. Hal tersebut tidak terlepas dari tuntutan masyarakat selaku konsumen semakin lama semakin tinggi. Tuntutan tersebut sejalan dengan semakin meningkatnya daya kritis masyarakat. Perusahaan yang selalu berupaya menjaga reputasinya di mata konsumen memiliki kecenderungan untuk mendapatkan dukungan dari masyarakat. Hal yang sama juga berlaku pemerintahan (Prayudi, 2012).

\section{Peranan Branding}

Dalam dunia usaha, keberadaan branding mempunyai peranan yang sangat penting, terutama bagi konsumen. Keller dalam Fandi Tjiptono (2005), menyebutkan bahwa ada tujuh manfaat yang dimiliki branding, diantaranya adalah sebagai berikut: 1) sebagai identifikasi sumber produk; 2) penetapan tanggung jawab pada manufaktur atau distributor tertentu; 3) signal kualitas; 4) alat untuk memperoyeksi citra diri; 5) ikatan khusus dengan produsen; 6) penekanan biaya pencarian internal dan eksternal; 7) pengurang resiko.

Keberadaan brand (merk) menjadi sebuah value indicator bagi semua stakeholder; diantaranya staf, pengelola, investor, dan pelanggan. Produk yang memiliki brand lebih bernilai di mata konsumen daripada produk yang tidak memiliki brand (Masruroh, 2018).

\section{Strategi Branding}

Menurut Kotler (2009), strategi branding memiliki beberapa komponen, diantaranya adalah sebagai berikut:

\section{1) Brand Positioning}

Brand positioning merupakan sebuah strategi pemasaran yang memiliki fungsi untuk membuat perbedaan mengenai manfaat dan keuntungan tertentu bagi konsumen sehingga mereka bisa mengingat brand tersebut. Brand positioning wisata memiliki maksud agar wisatawan mudah 
membedakan antara suatu tempat wisata dengan tempat wisata lainnya. Positioning yang baik tentu akan menghasilkan dampak serta respon yang baik dari pasar. Posisioning juga dapat menciptakan keberadaan (being) dan kredibilitas sebuah produk atau jasa.

2) Brand Personality

Brand Personality adalah sebuah upaya bagi perusahaan atau pelaku usaha untuk menambah nilai plus bagi sebuah brand dari luar di mata konsumen. Cara untuk menambah nilai plus dan daya tarik dari brand adalah melalui pengalaman konsumen lain, atau bisa melalui komunikasi pemasaran yang memperkenalkan brand itu sendiri. Cara ini juga bisa membantu pihak marketing untuk bisa memahami letak kelebihan dan kekurangan brand sehingga berpengaruh pada cara yang tepat untuk mempromosikan produk tersebut (Masruroh, 2018).

3) Brand Identity

Menurut Susanto dan Wijarnoko (Susanto, 2004); brand identity merupakaan serangkaian kata, kesan dan sejumlah persepsi dari konsumen mengenai brand atau merek sebuah produk. Adanya brand identity bisa membantu mengidentifikasi persepsi konsumen tentang sebuah brand.

\section{Tinjauan tentang Pariwisata \\ Pengertian Pariwisata}

Pengertian pariwisata berdasarkan UndangUndang nomor 10 tahun 2009 tentang Kepariwisataan merupakan segala hal yang mengandung unsur keindahan, keunikan, dan daya nilai yang menyangkut aneka ragam kekayaan alam, potensi budaya, dan hasil rekayasa karya manusia sehingga menarik dijadikan kunjungan wisata.

Menurut Suwantoro (Suwantoro, 2002) pariwisata adalah kegiatan bepergian sementara yang dilakukan oleh seseorang atau lebih ke suatu tempat di luar tempat tinggalnya. Adapun tujuannya adalah didorong oleh berbagai kepentingan, yang meliputi kepentingan ekonomi, politik, budaya, sosial, agama, pengetahuan, kesehatan, dan lain sebagainya. Namun demikian, istilah pariwisata berkaitan dengan perjalanan wisata yang mengandung unsur adanya perubahan tempat tinggal sementara yang dilakukan seseorang di luar tempat tinggalnya yang asli karena alasan tertentu yang bukan untuk aktivitas yang menghasilkan upah.

Yoeti (2008) menitikberatkan pengertian pariwisata sebagai suatu perjalanan ke tempat tertentu yang dilakukan hanya dalam jangka waktu yang sementara dengan tujuan di luar usaha mencari nafkah di tempat yang dikunjunginya, namun untuk tujuan rekreasi atau memenuhi keinginan lainnya yang beraneka ragam di luar urusan bisnis.

World Tourism Organization dalam Arjana (2015) mendefinisikan pariwisata sebagai kegiatan masyarakat untuk melakukan perjalanan dari tempat tinggalnya ke suatu tempat lainnya di luar lingkungannya dalam jangka waktu kurang dari satu tahun secara berturut-turut dengan tujuan untuk memanfaatkan waktu senggang, ataupun untuk urusan lainnya.

\section{Pengembangan Destinasi Wisata}

Beberapa komponen yang perlu dipenuhi dalam upaya pengembangan destinasi pariwisata, diantaranya adalah sebagai berikut (Sunaryo, 2013):

a. Atraksi, yakni daya tarik objek pariwisata yang meliputi daya Tarik yang berbasis pada potensi kekayaan alam, kekhasan budaya, maupun buatan manusia.

b. Aksesibilitas, meliputi dukungan sistem transportasi terhadap akses pariwisata, seperti; alat transportasi, jalur transportasi, fasilitas terminal, bandara, atau pelabuhan serta moda transportasi lainnya.

c. Amenitas, meliputi fasilitas pendukung kegiatan pariwisata, seperti: penginapan, rumah ibadah, tempat beristirahat, rumah makan, toko cinderamata, fasilitas penukaran atau pencairan uang, pusat informasi wisata, agen perjalanan, dan fasilitas-fasilitas yang dibutuhkan lainnya.

Di luar komponen utama di atas yang dikenal sebagai komponen pendukung pengembangan pariwisata, ada juga faktor penghambat pengembangan pariwisata, yakni tidak adanya sarana dan prasarana pendukung, baik yang dilakukan oleh pihak pemerintah setempat maupun pihak yang berwenang. Tidak tersedianya fasilitas pendukung atau keterbatasan prasarana dan sarana dalam pengelolaan potensi pariwisata biasanya berkaitan erat dengan kurangnya alokasi anggaran dana yang tersedia bagi pengembangan sektor pariwisata (Sunaryo, 2013).

\section{Jenis-jenis Pariwisata}

Nyoman S. Pendit (2003) dalam bukunya "Ilmu Pengetahuan Pariwisata: Sebuah Pengantar Perdana" menjelaskan tentang beberapa jenis pariwisata, diantaranya adalah sebagai berikut:

1. Wisata Budaya; bertujuan untuk berkunjung ke suatu tempat guna memperluas pandangan atau mindset terkait keadaan, kebiasaan, adat istiadat, budaya, dan seni masyarakat setempat. 
2. Wisata Kesehatan; perjalanan atau kunjungan wisata yang bertujuan untuk bisa mengobati penyakit atau kelelahan jasmani dan rohani di lokasi yang dikunjungi, seperti mandi atau terapi di sumber air panas atau ke tempat yang menyediakan fasilitas kesehatan lainya.

3. Wisata Olah Raga; perjalanan atau kunjungan pariwisata yang memiliki tujuan berolahraga atau berpartisipasi dalam kegiatan pesta olahraga di suatu tempat atau negara, seperti Asia Games, Olimpiade, dan event olahraga lainnya.

4. Wisata Komersial; bertujuan untuk mengunjungi pameran atau kegiatan yang bersifat komersil seperti pameran industri, pameran dagang, pameran UMKM dan lain sebagainya.

5. Wisata Industri; bertujuan untuk melakukan kunjungan ke lokasi atau tempat industri seperti pabrik atau perusahaan besar dengan tujuan untuk meninjau, meneliti, dan menimba pengetahuan. Kegiatan ini biasanya dilakukan oleh rombongan pelajar atau mahasiswa atau sekelompok orang yang memiliki kepentingan terhadap industry yang bersangkutan.

6. Wisata Politik; yakni perjalanan yang dilakukan dengan tujuan berkunjung atau berpartisipasi dalam pariwisata kegiatan politik, seperti perayaan ulang tahun sebuah Negara, penobatan kepala daerah tertentu, dan lain sebagainya.

7. Wisata Konvensi; meliputi fasilitas bangunan dengan ruangan-ruangan mirip tempat bersidang, konvensi atau pertemuan lainnya. Fasilitas ini banyak disediakan di berbagai Negara destinasi wisata yang memiliki jejak kesejarahan terkait konvensi tertentu. Misalnya seperti gedung Asia Afrika, dan lain sebagainya.

8. Wisata Sosial; berujuan untuk memberi kesempatan kepada masyarakat yang memiliki ekonomi lemah untuk berwisata dengan cara mengelola dan mengorganisir kegiatan wisata bersama mereka.

9. Wisata Pertanian; pariwisata yang bertujuan berkunjung ke daerah proyek pertanian atau perkebunan. Pariwisata ini banyak ditemui di daerah yang memiliki potensi alam yang subur dan memiliki kekhasan hasil bumi tertentu, seperti kebun apel di Kota Malang.

10. Wisata Bahari; berkaitan dengan pariwisata perairan, seperti memancing, berperahu di danau, berjemur di pantai, berlayar di lautan, kegiatan menyelam, berselancar, dan lain sebagainya.

11. Wisata Cagar Alam; wisata yang bertujuan ke lokasi cagar alam atau hutan lindung.
12. Wisata Buru; wisata ke daerah, hutan atau tempat berburu yang dibenarkan oleh pemerintah.

13. Wisata Pilgrim; pariwisata yang bertujuan berkunjung ke tempat-tempat suci, ke makammakam orang besar atau leluhur, perjalanan ke bukit atau gunung yang dikeramatkan, dan lokasi lainnya yang dianggap memiliki tuah dan memiliki jejak sejarah.

14. Wisata Bulan Madu; bertujuan untuk perjalanan yang dilakukan oleh pasangan pengantin baru. Pariwisata ini biasanya diselenggarakan oleh agen atau biro perjalanan khusus pengantin baru dengan fasilitas tertentu.

15. Wisata Petualangan; bertujuan untuk melakukan kegiatan bertualang ke hutan atau lokasi yang dianggap ekstrem, seperti hutan belantara, perbukitan yang terjal, arung jeram menyusuri goa, kegiatan susur pantai, dan lain sebagainya.

\section{METODE PENELITIAN}

Dalam penelitian ini, peneliti menggunakan metode kualitatif dengan menggunakan teknik wawancara, observasi, dan dokumentasi untuk pengumpulan data agar mendapatkan data yang objektif. Penelitian kualitatif merupakan suatu prosedur penelitian yang membuat data secara deskriptif baik berupa kata-kata dan perilaku dari orang-orang yang diteliti (Arikunto, 2006). Sumber data penelitian ini memperhatikan tiga instrument penelitian pada jenis kualitatif, yaitu pelaku (actors), kegiatan (activity), dan tempat (place) (Arikunto, 2006). Dalam pengambilan data, penggunaan sumber data ini menggunakan purposive sampling. Purposive sampling merupakan sebuah teknik bagaimana mencari sampel yang didasarkan pada penilaian penelitian tentang siapa saja yang layak dijadikan sampel.

Peneliti memilih subjek berdasarkan kriteria sebagai berikut yaitu Dinas Pariwisata Kab. Garut yang bertanggungjawab atas program branding kabupaten Garut sebagai destinasi wisata. Sementara Objek penelitian ini adalah bagaimana branding kabupaten garut sebagai destinasi wisata di masa pandemi.

Adapun teknik pengumpulan data dilakukan melalui beberapa cara diantaranya adalah wawancara, observasi, dan dokumentasi. Observasi adalah melihat kegiatan sehari-hari yang dilakukan narasumber. Wawancara adalah proses memperoleh keterangan untuk tujuan penelitian dengan cara tanya jawab sambil bertatap muka antara penanya (pewawancara) dengan penjawab 
(informan) dengan menggunakan alat yang dinamakan interview guide (panduan wawancara) (Nazir, 1998). Dokumentasi dilakukan guna mencari data mengenai hal-hal yang dianggap relevan dengan penelitian yang meliputi berupa buku, surat kabar, biografi, catatan, transkip, majalah, agenda, prasasti, notulen rapat dan lain sebagainya (Arikunto, 2006).

\section{HASIL DAN PEMBAHASAN}

\section{Strategi Branding Wisata Garut}

Sebagaimana dipaparkan oleh Kotler (2009), bahwa strategi branding meliputi beberapa komponen, diantaranya meliputi: brand posisioning, brand personality, dan brand identity.

\section{a. Brand Posisioning}

Brand positioning bertujuan untuk menciptakan perbedaan, manfaat, keuntungan yang membuat konsumen selalu ingat dengan suatu produk. Kaitannya dengan wisata, brand positioning di bidang wisata bertujuan untuk membantu para pengunjung lokasi wisata mengidentifikasi perbedaan unik antara satu destinasi wisatu dengan destinasi yang lain.

Garut memiliki banyak kawasan yang cukup strategis untuk pengembangan wisata. Di masa pandemi ini, Wisata-wisata alam seperti pegunungan, pantai, sungai, dan lain sebagainya cukup menjadi tempat yang digemari masyarakat. Terlebih lagi beberapa tempat wisata tertutup seperti kolam renang, karaoke, spa, dan bioskop memang masih belum disarankan untuk beroperasi karena dianggap sebagai tempat yang rentan menjadi penyebaran covid 19.

Posisioning wisata yang dimiliki oleh Garut tidak terlepas dari keunikan lokasi wisata yang ada di dalamnya. Untuk meneliti aspek keunikan ini, peneliti meninjaunya dari beberapa aspek, yakni aspek pemerintah daerah garut dan serta pengelola daerah wisata, dan dari aspek pengunjung wisata.

Berdasarkan Perda No 2 Tahun 2019 tentang Rencana Induk Pembangunan Kepariwisataan Daerah Kabupaten Garut 2019-2025, Pemerintah Daerah membagi pengembangan kawasan pariwisata ke dalam beberapa konsep pengembangan diantaranya dengan pembagian wilayah pengembangan yang meliputi Kawasan Strategis Pariwisata Kabupaten (KSPK) dan Kawasan Pengembangan Pariwisata Kabupaten (KPPK). Adapun pengembangan KSPK kabupaten Garut meliputi Perkotaan Garut, Garut Tengah, Garut Utara, dan Garut Selatan. Masing-masing KSPK dan KPPK memiliki keunggulannya masing-masing.

KSPK Perkotaan Garut mengembangkan potensi wisata dalam aspek ekowisata dan wisata berbasis air panas (cipanas), pengembangan wisata situ bagendit, serta pengembangan wisata kreatif sebagai pendukung utama kunjungan wisata, seperti kawasan sentra kerajinan kulit, kampung sutra, batik garutan, pabrik dodol garut, akar wangi, dan lain sebagainya. KSPK Garut Utara memiliki cagar wisata Candi Cangkuang, Talagabodas, dan Agrowisata Malangbong. KSPK Garut Tengah meliputi pengembangan kawasan pariwisata Darajat, Gunung Papandayan, Situs Ciburuy, dan Curug (Air terjun). Sementara KSPK Garut Selatan meliputi ekowisata alam perbukitan dan Ekowisata pantai, seperti Santolo, Rancabuaya, Sayang heulang, Pantai Cimahi dan lain sebagainya.

$$
\text { Untuk pengembangan Kawasan }
$$

Pengembangan Pariwisata Kabupaten (KPPK) meliputi aspek pengembangan pariwisata warisan budaya (heritage) dan situs, seperti Kawasan Budaya Cibatu, Karacak Valley (Perkebunan Dayeuh Manggung), Situs Linggaratu, Wisata Ziarah Makam Sunan Godog, Desa Wisata Ciburial dan Desa Wisata Samida. Semua pengembangan potensi wisata ini sebagaimana tertuang dalam Perda No tahun 2019 tentang Rencana Induk Pembangunan Kepariwisataan Daerah 2019-2025.

Posisioning garut yang memiliki sejumlah fasilitas wisata alam memiliki daya tawar tersendiri bagi para wisatawan. Hal ini diperkuat lagi dengan dorongan pemerintah daerah Garut yang mengajak masyarakat untuk pengembangan desa wisata. Pengembangan desa wisata bertujuan agar di setiap desa itu menjadi tujuan wisata. Dua desa yang menjadi unggulan di Kabupaten Garut adalah desa ciburial di samarang dan desa bagendit. Salah satu dari dua desa ini menjadi runner-up desa wisata pada lomba tingkat nasional. Hal ini sebagaimana disampaikan oleh Ibu sopi peridiansah selaku kepala Subbagian Umum dan Kepegawaian Dinas Pariwisata Kabupaten Garut, bahwa prestasi tersebut diharapkan bisa terus mendorong masyarakat untuk mengelola dan membuka spot kepariwisataan di desanya masingmasing dengan tetap mempertahankan suasana desa yang sejuk dan alami.

Menurut salah satu pengunjung wisata Situ Bagendit, Garut menjadi tempat alternatif wisata yang cukup bagus karena memiliki beberapa kelebihan. Selain karena pengelolaan tempat wisatanya yang semakin baik, dan promosi wisata yang semakin gencar di media sosial membuat wisatawan luar juga semakin banyak berdatangan ke garut, Garut juga 
memiliki area wisata yang cukup terkenal, yakni cipanas (air panas). Cipanas merupakan lokasi wisata yang cukup digemari oleh masyarakat, baik wisatawan lokal maupun pendatang. Hal itu dikarenakan di cipanas terdapat kolam renang (pemandian) yang memiliki air panas alami yang berasal dari gunung berapi yang ada di sekitarnya. Air panas ini mengandung belerang yang dipercaya bisa menyembuhkan penyakit kulit ataupun bisa untuk sekedar melakukan terapi. Meskipun memiliki kandungan belerang, air cipanas garut tidak memiliki bau belerang sebagaimana cipanas di daerah lainnya ${ }^{1}$.

Beberapa lokasi wisata garut yang menjadi tempat favorit baginya diantaranya adalah pemandian air panas, situ cangkuang dan Situ bagendit, candi, pengunungan, dan talaga bodas. ${ }^{2}$

\section{b. Brand Personality}

Brand personality merupakan kesan konsumen atau pengunjung dalam pelayanan wisata di kabupaten garut. Kesan atau pendapat ini meliputi kesan baik (positif) dan kesan buruk (negatif). Kesan atau pendapat dari konsumen ini diharapkan bisa menjadi bahan bagi pengelola wisata untuk meningkatkan pelayanannya.

Menurut salah satu pengunjung pantai santolo (pantai di Garut Selatan), Garut memiliki banyak kawasan yang indah dan cocok untuk dikunjungi, terutama di masa pandemi. Menurutnya, kondisi alam dan keadaan alam Garut sangat cocok untuk melepas penat, terutama bagi dirinya yang sengaja bermotor bersama teman-temannya. Ia melakukan touring dengan menggunakan sepeda motor bersama tujuh teman lainnya ${ }^{3}$.

Selain pantai, pengunjung juga bisa memilih pegunungan di Kabupaten sebagai lokasi wisatanya. Seperti Puncak Guha, yang memiliki paronama pegunungan yang sangat indah dan alami. Lokasi ini sangat cocok untuk camping dan melakukan pendakian. Puncak Guha merupakan lokasi wisata yang baru populer sejak masa pandemi. Selain itu, beberapa lokasi wisata yang bisa dijadikan alternatif selama pandemi adalah Gurun pasir di daerah rancabuaya, Candi Cangkuang, situ Bagendit, Gunung Papandayan, Kamojang, Cipanas, Curug Cisompet, dan Gunung Guntur ${ }^{4}$.

\footnotetext{
${ }^{1}$ Hasil wawancara terhadap Yanri Pratiwi, PNS Penyuluh Narkoba (PNS) BNN Garut pada 12 Juni 2020.

${ }^{2}$ Wawancara dengan Yanri Pratiwi pada 12 Juni 2020.

${ }^{3}$ Wawancara dengan Hannan syahra Raudhah, wiraswasta pada 21 Juni 2020.
}

Namun demikian, menurut Hannan ${ }^{5}$ ada kesan negatif yang didapatkannya terkait lokasi wisata yang ia datangi. Kesan negatif tersebut menyangkut tarif harga masuk yang lebih mahal dari biasanya. Hal ini dikarenakan disamping harganya mahal, tarifnya juga tidak memiliki nota khusus (karcis). Momen wisata di masa pandemi ini seolah disalah gunakan oleh warga sekitar dengan memberlakukan harga masuk yang tidak wajar. Padahal menurut informasi yang didapatkannya berdasarkan kebijakan daerah, lokasi wisata daerah tersebut Gratis.

Kesan negatif lainnya berasal dari pendapat Ibu Yanri Pratiwi ${ }^{6}$ yang beranggapan bahwa dampak negatif dari kemajuan Garut sebagai destinasi wisata adalah tingkat kemacetan yang semakin parah. Menurutnya, kalau dulu Garut macet hanya pada saat weekend, yakni saat banyak wisatawan dari luar daerah datang ke garut untuk tujuan wisata. Sekarang, hampir tiap hari garut macet. Hal ini dikarenakan pemerintah daerah seolah kurang memiliki kesiapan dalam memberikan fasilitas pelebaran jalan bagi datangnya wisatawan dalam jumlah yang semakin hari semakin besar. Ia berharap perkembangan garut sebagai kota wisata dibarengi pula dengan pengembangan di sektor lainnya.

\section{c. Brand Identity}

Brand Identity meliputi keunggulan dan ikon yang dimiliki kabupaten garut sebagai kota wisata. Berdasarkan wawancara dengan para stakeholders, dinas pariwisata, pelaku usaha, dan pengunjung, keunggulan kota garut terletak pada kondisi geografisnya yang menawarkan lokasi wisata alam yang cukup strategis untuk dijadikan tempat wisata.

Ikon lainnya yang dimiliki Garut adalah dodol Garut. Di bidang wisata kuliner, keberadaan dodol Garut bukan sesuatu yang baru lagi. Dodol garut sudah populer tidak hanya di kalangan wisatawan lokal, tapi juga di manca negara. Karena memang pemasarannya sudah memasuki ranah pasar ekspor. Selain mengangkat brand makanan tradisional khas Garut, dodol garut juga memiliki varian yang beragam sehingga cocok sebagai buah tangan atau oleh-oleh. Belum lama ini, Garut mendapatkan slogan baru sebagai kota dodol. Tentu hal ini menjadi ikon tersendiri untuk menaikkan pamor Garut sebagai kota wisata tidak hanya bagi Pemerintah Daerah Garut, tapi juga bagi UMKM pelaku usaha bidang dodol. Hal ini

\footnotetext{
${ }^{4}$ Wawancara dengan Hannan Syahra Raudhah, Mirswasta, pada 21 Juni 2020.

${ }^{5}$ Wawancara dengan Hannan Syahra Raudhah, Mirswasta, pada 21 Juni 2020.

${ }^{6}$ Wawancara dengan Yanri Pratiwi pada 12 Juni 2020.
} 
terungkap dalam wawancara terhadap Tanto Rieza, Kepala Pemasaran Online Dodol Picnic Garut. Pak Tanto Rieza menuturkan bahwa branding wisata Garut tidak lepas dari Dodol Piknik yang menyasar masyarakat umum meskipun dodol masuk dalam segment yang sangat khusus. Karena dodol picnic merupakan product budaya warisan yang memang harus dilestarikan tidak hanya orang tua tetapi anakanak termasuk juga milenial, maka sangat layak jika dodol piknik menjadi salah satu ikon bagi kuliner dan pariwisata, khususnya di Kabupaten Garut. Dodol Garut tidak hanya memiliki ciri khas yang mengandung nilai budaya dan sejarah, namun juga memiliki nilai edukasi tentang pentingnya melestarikan budaya bangsa. Jadi kesimpulannya ikon dodol bagi kabupaten Garut bukan hanya memiliki nilai bisnis tetapi menjadi juga eduwisata. ${ }^{7}$

Selain dodol, Garut juga terkenal dengan beberapa aneka jajanan dan kuliner lainnya seperti Ubi Cilembu, Kue Ladu dan Endog Lewok dari Malangbong, Kerupuk Dorokdok Sukaregang, Kopi Garut, dan lain sebagainya. Di Bidang UMKM Garut juga memiliki ciri khas yang tidak dimiliki daerah lainnya, seperti aneka produk kulit Sukaregang Garut, Batik Garutan, Boboko Samarang, dan lain sebagainya. Khusus produk kulit, Kulit Garut tidak hanya terkenal di dalam negeri, tapi juga di manca Negara. Produk kulit asal Garut mampu bersaing dengan produk kulit luar negeri yang ber-merk. Buktinya, banyak produk kulit garut juga yang bisa diekspor ke luar negeri ${ }^{8}$.

\section{Strategi Branding Pelaku Usaha Pariwisata Garut di Masa Pandemi}

Masa pandemi covid 19 ditandai dengan merebaknya virus corona sejak akhir tahun 2019 di berbagai belahan dunia. Kasus virus corona masuk ke Indonesia sejak 2 Maret 2020 ketika Presiden mulai mengumumkan pasien positif corona pertama. Setelah itu, kasus baru terus bermunculan setiap harinya dengan penambahan jumlah yang cukup bervariasi. Hingga akhir Maret 2020, kasus baru muncul pada kisaran 2 hingga 82 kasus per-harinya. Angka ini terus bertambah hingga menembus angka 100 setiap harinya (tirto.id, 2020).

Tidak lama sejak saat itu, penyebaran virus ini cukup significant ke berbagai wilayah di Indonesia, tidak hanya perkotaan tapi juga merambah ke pelosokpelosok desa di berbagai daerah di Indonesia. Pemerintah kemudian mengeluarkan kebijakan untuk menghentikan beberapa sekotor yang dianggap

\footnotetext{
${ }^{7}$ Hasil wawancara terhadap Pak Tanto Rieza, Kepala
} Marketing Dodol Piknik Garut, pada 2 Agustus 2020. menjadi cluster penyebaran covid 19, seperti Mall, Pabrik, sekolah, perkantoran, dan lain sebagainya. Pemerintah kemudian menyarankan agar masyarakat bekerja, belajar dan beraktivitas dari rumah melalui layanan online atau daring (dalam jaringan), yang dikenal dengan slogan \#DiRumahSaja.

Selain itu, untuk memutus mata rantai penyebaran covid 19, pemerintah menggalakkan kebijakan pembatasan sosial berskala besar atau dikenal dengan istilah PSBB di beberapa daerah yang dianggap menjadi zona merah atau kuning. Pemberlakukan PSBB sebagai upaya memperkuat penerapan pembatasan fisik (physical distancing) pada masyarakat untuk mencegah penyebaran covid 19 (virus corona). Penerapan kebijakan PSBB itu diatur dalam PP Nomor 21 Tahun 2020 tentang Pembatasan Sosial Berskala Besar dalam Rangka Percepatan Penanganan Covid-19 yang ditandatangani oleh Presiden Joko Widodo. Kemudian, dalam pelaksanaan PP tersebut diturunkan melalui Peraturan Menteri Kesehatan Nomor 9 Tahun 2020 tentang Pedoman PSBB (nasional.kompas.com, 2020).

Adanya pertimbangan kebijakan \#DiRumahSaja yang membawa dampak yang cukup signifikan, terutama bagi perekonomian, akhirnya pemerintah kembali membuat kebijakan untuk memperbolehkan beroperasinya kembali Mall, Pusat Perbelanjaan, Toko, Warung, Pasar, serta sektor-sektor perekonomian penting lainnya dengan penerapan protokol kesehatan. Era ini disebut sebagai new normal, yakni masa adaptasi kebiasaan baru bagi masyarakat untuk selalu menerapkan protokol kesehatan di manapun berada, seperti menggunakan masker, cuci tangan dengan sabur atau memakai hand sanitizier, dan jaga jarak (phisyical distancing). Protokol kesehatan ini diterapkan guna mencegah terjadinya penularan covid 19 yang bahkan bisa menyebar melalui orang tanpa gejala (OTG).

Setelah melihat dampak ditutupnya beberapa industri dan beberapa sektor ekonomi lainnya, pemerintah akhirnya memberlakukan new normal untuk mengatasi kemandegan ekonomi tersebut. Pemerintah melalui Kementerian Kesehatan (Kemenkes) mengeluarkan peraturan terkait protokol peralihan dari PSBB menuju new normal. Peraturan mengenai protokol ini sebagai pedoman bagi pekerja dan dunia usaha melalui keputusan nomor HK.01.07/MENKES/328/2020 pada 20 Mei 2020 tentang Panduan Pencegahan dan Pengendalian COVID-19 di Tempat Kerja Perkantoran

\footnotetext{
${ }^{8}$ Hasil wawancara dengan Bapak Iwan, pengunjung dan pembeli produk kulit sukaregang, pada 15 Agustus 2020.
} 
dan Industri dalam upaya mendukung hidupnya dan berlangsungnya perekonomian dan dunia Usaha pada Situasi Pandemi (tirto.id, 2020).

Pemberlakuan New normal yang diterapkan pemerintah sejak awal Juni 2020 memberikan angin segar bagi bergeraknya roda perkenomian, termasuk pada sektor wisata yang sebelumnya juga sempat dihentikan. Hal ini dikarenakan pariwisata dianggap sebagai sektor yang bisa melahirkan geliat kembali sektor perekonomian daerah, bahkan nasional. Dibukanya sektor wisata juga tetap menerapkan protokol kesehatan. Hal ini sebagaimana yang disampaikan oleh Ibu Sopi Peridiansah, kepala Sub bagian Umum dan Kepegawaian Dinas Pariwisata Kabupaten Garut. Menurutnya pemerintah kabupaten hanya membolehkan pelaku usaha wisata membuka tempat wisata yang sifatnya terbuka seperti gunung, pantai, kebun, dan lain sebagainya. Hal itupun dengan syarat tetap harus mengikuti protokol kesehatan. Menurutnya, dinas pariwisata membuat kebijakan di internal terlebih dahulu yang melibatkan stakeholders di bidang pariwisata untuk menerapkan protokol kesehatan di lingkungan wisata agar pengunjung merasa aman dan nyaman ketika berwisata. Disamping menyusun SOP, dinas pariwisata juga telah mengundang para rekanan di dunia wisata untuk membuat standar kesehatan yang akan diterapkan di tempat wisata masing-masing. Hal tersebut dilakukan sebelum dinas terkait membuat surat resmi mengenai pembukaan tempat wisata kepada masyarakat ${ }^{9}$. Kebijakan tersebut tentu dibuat sesuai dengan keputusan pusat terkait new normal.

Hal yang sama juga ditegaskan oleh Bapak Endang Heri selaku KPUT Bagendit (Unit Pelaksana Teknis). Ia menyampaikan bahwa kebijakan pembukaan lokasi wisata berdasarkan perhitungan zona. Karena Garut masuk pada zona yang dianggap aman, yakni zona biru, maka pemerintah daerah membuka kembali usaha wisata di kabupaten Garut dengan dasar surat izin dari bupati Garut. Namun demikian syarat utamanya adalah lokasi wisata tersebut melakukan SOP yang telah disusun untuk menghadapi new normal ini ${ }^{10}$.

Selain itu, upaya untuk memaksimalkan seluruh potensi yang ada juga dilakukan. Salah satunya adalah

\footnotetext{
${ }^{9}$ Hasil wawancara dengan Ibu Sopi Perdiansah, pada 6 Juli 2020.

${ }^{10}$ Hasil wawancara dengan Bapak Endang Heri, pada 10 Juli 2020.

${ }^{11}$ Hasil wawancara dengan Bapak ILham Farhansyah, pada 23 Agustus 2020.
}

dengan melakukan kerjasama yang intensif dengan seluruh pihak yang berhubungan dan berkaitan dengan keberlangsungan pariwisata. Hal ini sebagaimana diungkapkan oleh Bapak Ilham Farhansyah, selaku pelaku usaha di bidang travel. Menurutnya kerjasama yang baik antar pelaku usaha di bidang pariwisata akan membantu bangkit dari keterpurukan akibat lesunya usaha karena pandemi. Beberapa pihak yang diajak kerjasama diantaranya terkait perizinan perjalanan, destinasi wisata, resto, serta tempat usaha kuliner sebagai upaya memberikan pelayanan, konsumsi, dan oleh-oleh yang terbaik. Dinas pariwisata dan dinas kesehatan tentu menjadi pihak yang paling utama sebagai stakeholders pemerintah dalam pelayanan pariwisata di masa pandemi ini. Selain karena alasan wisata, keselamatan jiwa para wisatawan tentu harus menjadi prioritas bersama selama dalam perjalanan aktivitas wisata, yakni dengan penerapan perototkol kesehatan yang dianjurkan selama berwisata ${ }^{11}$.

Brand Posisioning, Brand Personality, dan Brand Identity dilakukan melalui upaya promosi pariwata dengan pemanfaatan media massa, baik media mainstream maupun media online. Biasanya promosi bisa dilakukan di tempat-tempat ramai seperti pameran, konser musik, bazar, dan lain sebagainya, akan tetapi pada masa pandemi ini, promosi hanya bisa dilakukan melalui media, terutama media sosial ${ }^{12}$.

Menurut Pak Tanto Rieza ${ }^{13}$, sejak diberlakukannya new normal, stategi branding pelaku usaha kuliner dan wisata mengalami penyesuaian. Dari sisi management melakukan upaya re-organisasi struktur atau melakukan penyederhanaan managemen namun tetap sesuai dengan target-target yang telah ditetapkan oleh perusahaan. Hal itu dilakukan mengingat nasib sekian ratus karyawan bergantung pada jalannya perusahaan. Sementara strategi branding yang dilakukan adalah fokus pada optimalisasi pemasaran online.

Beberapa Media online yang pengunjung tahu terkait lokasi wisata di kabupaten Garut diantaranya adalah akun Instagram Jelajah Garut, info Garut, dan Garut Update $^{14}$.

Strategi dalam usaha travel juga mengikuti penyesuaian sebagaimana aturan tentang transportasi di masa pandemi, seperti seperti kursi duduk yang

\footnotetext{
12 Hasil wawancara terhadap sopi peridiansah, kepala Subbagian Umum dan Kepegawaian Dinas Pariwisata Kabupaten Garut, pada 6 Juli 2020.

${ }^{13}$ Hasil wawancara dengan Pak Tanto Rieza, pada 2 Agustus 2020.

${ }^{14}$ Wawancara dengan Hannan Syahra Raudhah, Mirswasta, pada 21 Juni 2020.
} 
diberi jarak, jumlah orang yang di dalam mobil hanya setengahnya, misalnya dari yang harusnya 60 seat menjadi 30 seat saja. Selain itu diadakan open trip dengan harga terjangkau khusus daerah wisata yang dibuka dengan menggunakan potongan harga. Hal ini sebagai upaya menarik kembali para wisatawan untuk menggunakan jasa travel ${ }^{15}$.

Selain mempromosikan wisata setempat, branding berbagai media juga membantu menginformasikan tentang protokol kesehatan yang tetap harus dipatuhi para pengunjung selama di area wisata, yakni menggunakan masker, mencuci tangan dengan sabun, dan menjaga jarak dengan pengunjung lainnya. Selain itu, sebelum memasuki area wisata, petugas juga dilengkapi dengan alat pengukur suhu tubuh agar setiap pengunjung yang datang bisa dicek suhu tubuhnya terlebih dahulu ${ }^{16}$.

\section{Tantangan di Masa Pandemi}

Kebutuhan masyarakat akan rasa rileks melalui wisata menjadi peluang di satu sisi, namun menjadi tantangan di sisi yang lain. Tantangan tersebut tidak lain karena penyebaran covid 19 yang masih terus bertambah membuat sebagian masyarakat masih takut untuk bepergian dan melakukan wisata. Hal ini tentu berdampak pada Pendapatan Asli Daerah (PAD) yang tidak tercapai. Roda perekonomian yang lesu membuat sebagian masyarakat tidak memiliki daya beli dan daya jangkau terhadap wisata itu sendiri. Tantangan lainnya adalah fasilitas kesehatan yang harus disediakan oleh pihak pengelola wisata. Hal itu bukan hal yang mudah dilakukan mengingat berkaitan dengan budaya masyarakat yang masih rendah terkait kebersihan, kesadaran akan pentingnya menjaga kesehatan juga masih dipertanyakan ${ }^{17}$.

Dalam kondisi normal, cipanas menjadi tempat favorit bagi para wisatawan untuk berenang dan bermain air. Namun di masa pandemi, pamor cipanas menurun karena kolam renang belum menjadi tempat yang direkomendasikan pihak dinas kesehatan. Lokasi pegunungan, air terjun dan pantai menjadi tempat favorit baru.

Hal ini terungkap dalam wawancara kepada beberapa pengunjung wisatawan. "Inginnya pergi berenang, namun masih dipikirkan dahulu dari segi

\footnotetext{
15 Hasil wawancara dengan Bapak ILham Farhansyah, pada 23 Agustus 2020

${ }^{16}$ Hasil wawancara dengan Endang Heri, Unit Pelaksana Teknis Bagendit kabupaten garut, pada 10 Juli 2020.

17 Hasil wawancara dengan Endang Heri, Unit Pelaksana Teknis Bagendit kabupaten garut, pada 10 Juli 2020.
}

keamanannya, karna tidak seperti didarat, kita mudah untuk jaga jarak dengan pengunjung lain, namun di kolam renang akan sulit, membuat kita juga masih pikir-pikir untuk pergi ke kolam"18. Menurutnya daerah pegunungan menjadi alternatif, karena selain udaranya yang segar, cuaca dan iklimnya juga membuat segar ke badan. Hal ini bukan berarti tempat lain tidak baik, namun pegunungan tetap menjadi tempat terbaik untuk menghirup udara yang masih segar dan jauh dari polusi.

Pendapat lainnya disampaikan oleh Ibu Rasmini ${ }^{19}$ Menurutnya daerah pegunungan yang cukup populer di Garut adalah kamojang karena berasa ada di surga dunia. Tempatnya sangat cocok untuk melepas penat sebab di sana banyak penghijauan, suasananya pun dingin, adem, dan tidak bising dengan suasana kota. $\mathrm{Bu}$ Rasmini berpendapat bahwa sejauh ini perbenahan Garut luar biasa dalam aspek wisata. Walaupun belum sebanyak bandung, namun garut sudah cukup baik untuk sekedar menghilangkan penat dan melihat viewview menarik. Kelebihan lain menurutnya adalah harga masuk lokasi wisata di garut relatif terjangkau dan ekonomis.

Namun catatan yang disampaikan oleh Bu Rasmini adalah berkaitan kondisi new normal adalah tidak semua masyarakat di sekitar lokasi wisata yang taat protokol kesehatan. Dirinya masih melihat orang yang tidak mengenakan masker. Bahkan kesannya petugas kurang bersikap tegas terhadap pengunjung yang tidak mengenakan masker. Padahal menurutnya, penting bagi pelaku usaha wisata agar menerapkan protokol kesehatan dengan menyediakan masker atau sanitizier, baik dibagikan secara gratis atau dengan cara dijual kepada para wisatawan ${ }^{20}$.

Dinas pariwisata sebagai leading sektor wisata mengaku mendapatkan protes dari stakehoders dan pelaku usaha wisata karena banyaknya persyaratan yang harus mereka penuhi terkait protokol kesehatan. Di bidang Sumber Daya Manusia (SDM) juga tentu mengalami hambatan karena tidak semua orang dengan kondisi pandemi seperti ini tetap bisa berpikir bagaimana mencapai target kinerjanya sebagaimana job descriptionnya masing-masing ${ }^{21}$.

\footnotetext{
${ }^{18}$ Wawancara dengan Yanri Pratiwi pada 12 Juni 2020.

${ }^{19}$ Wawancara dengan Rasmini, Wiraswasta, berasal dari Kota Bandung pada 5 Agustus 2020.

${ }^{20}$ Wawancara dengan Rasmini, Wiraswasta, berasal dari Kota Bandung pada 5 Agustus 2020.

${ }^{21}$ Hasil wawancara dengan Ibu Sopi Peridiansah, Dinas Pariwisata Kab. Garut, pada 6 Juli 2020.
} 
Sementara tantangan yang dihadapi pihak pengusaha bidang pariwisata adalah berkaitan dengan menurunnya kunjungan wisata. Hal ini tentu sangat berpengaruh pada menurunnya geliat perekonomian, salah satunya di bidang pariwisata. Menurut Bapak Ilham ${ }^{22}$, Salah satu upaya untuk bertahan dalam masa pandemi adalah dengan membuat planning baru, artinya para pelaku usaha harus benar-benar bisa mempertahankan agar perusahaan hidup dengan berbagai usaha promo yang dilakukan dimasa pandemi ini. Selain itu, promosi kunjungan lebih banyak diarahkan pada wisata alam yang memang lokasinya terbuka, serta menghindari wisata yang berkerumun untuk mencegah penularan virus covid 19. Menjual harga tiket yang terjangkau, memberikan berbagai promo dan potongan harga, serta pemberian free masker untuk semua wisatawan yang menggunakan jasa kami juga dilakukan sebagai upaya meminimalisir tantangan-tantangan yang dihadapi selama pandemi.

\section{Kesimpulan}

\section{KESIMPULAN DAN SARAN}

Langkah awal dalam penentuan branding Kabupaten Garut sebagai destinasi wisata adalah pengkajian terhadap brand positioning karena Kabupaten Garut memiliki geografis alam yang memiliki potensi wisata yang tidak dimiliki daerah lain, memungkinkan garut memiliki pesona tersendiri untuk dikunjungi. Sebagai destinasi wisata, garut memiliki hampir semua potensi alam seperti cipanas, pantai, pegunungan, kawah, air terjun, goa, candi, telaga, gunung pasir, dan lain sebagainya. Selain itu Garut juga gencar mengembangkan desa wisata. Pengembangan desa wisata bertujuan agar di setiap desa itu menjadi tujuan wisata. Dua desa yang menjadi unggulan di Kabupaten Garut adalah desa ciburial di samarang dan desa bagendit. Salah satu dari dua desa ini menjadi runner-up desa wisata pada lomba tingkat nasional.

Strategi selanjutnya yaitu brand personality di mana dari penggalian terhadap brand positioning pemerintah dan pelaku usaha di bidang pariwisata bahu membahu membuat ide baru untuk membuat ciri khas yang unik dengan mengacu pada potensi yang dimiliki oleh kabupaten Garut, diantaranya seperti wisata ke pantai Santolo di Pameungpeuk (Garut Selatan), Mendaki di Puncak Guha dan Gunung Guntur, Perkemahan di Gunung papandayan, Gurun pasir di Pantai Rancabuaya, Wisata sejarah di Candi Cangkuang dan

22 Hasil wawancara dengan Bapak ILham Farhansyah, pada 23 Agustus 2020.
Situ Bagendit, Wisata puncak di Kamojang dan Darajat, Berenang dan berenang air panas di Cipanas, wisata Air Terjun di Curug Cisompet, Wisata Talaga Bodas, Perkebunan Teh Dayeuh Manggung, dan lain sebagainya.

Kemudian langkah yang terakhir adalah brand identity yang diharapkan bisa mewakili brand positioning dan brand personality. Brand identity diharapkan membantu menjadi alat untuk mengkomunikasikan personality dan positioning branding seperti apa yang ingin disampaikan komunikator (pelaku usaha) kepada target atau objek marketnya selaku komunikan, seperti yang khas di garut yang membantu branding wisata adalah di bidang kuliner dan UMKM. Di bidang kuliner seperti Dodol Garut, Ubi Cilembu, Kue Ladu dan Endog Lewok dari Malangbong, Kerupuk Dorokdok Sukaregang, Kopi Garut, dan lain sebagainya. Di Bidang UMKM seperti aneka produk kulit Garut, Batik Garutan, Boboko Samarang, dan lain sebagainya.

Brand Posisioning, Brand Personality, dan Brand Identity merupakan upaya branding yang saling melengkapi satu sama lain. Ketiga branding ini dilakukan melalui upaya promosi pariwata dengan pemanfaatan media massa, baik media mainstream maupun media online. Biasanya promosi bisa dilakukan di tempat-tempat ramai seperti pameran, konser musik, bazar, dan lain sebagainya, akan tetapi pada masa pandemi ini, promosi hanya bisa dilakukan melalui media, terutama media sosial.

Adapun tantangan yang dihadapi kabupaten Garut tidak terlepas dari penyebaran Covid 19 yang juga melanda pada hampir seluruh wilayah kabupaten Garut. Tantangan-tantangan branding wisata garut meliputi alasan ekonomi sehingga menurunkan daya beli masyarakat, termasuk berkunjung ke lokasi wisata. Tantangan lainnya adalah berkenaan dengan kurangnya disiplin prototokol kesehatan masyarakat sekitar area wisata, rendahnya kesadaran masyarakat tentang pentingnya kebersihan, kurang tegasnya petugas wisata dalam melakukan tindakan terhadap pengunjung yang tidak mematuhi protokol kesehatan, serta masih minimnya fasilitas kesehatan dan gugus tugas covid 19 di beberapa area wisata Garut.

\section{Saran}

Berdasarkan penelitian yang dilakukan, ada beberapa saran yang bisa diterapkan baik oleh Dinas Pariwisata Kabupaten lain maupun oleh pelaku usaha dari pihak swasta selaku rekanan dinas pariwisata dalam upaya 
perbaikan pengembangan destinasi wisata kabupaten Garut ke depan, baik dalam kondisi pandemic maupun kondisi normal, diantaranya adalah sebagai berikut:

1. Penerapan protokol kesehatan secara ketat tidak hanya bagi penyedia jasa pariwisata, tapi juga terhadap pengunjung area wisata.

2. Ketersediaan alat kesehatan dalam upaya protokol kesehatan seperti masker, hand sanitizier atau tempat cuci tangan, pengukur suhu tubuh, dan lain sebagainya yang dibutuhkan di area wisata.

3. Ketersediaan alat kampanye di media ruang terbuka seperti poster-poster atau spanduk dan semacamnya berkenaan dengan pentingnya menjaga kesehatan di area wisata.

4. Adanya kejelasan tarif yang diterapkan di area wisata melalui pemberian karcis resmi dari pihak pemerintah daerah atau dari pihak pengelola, dari mulai tariff parker, tarif masuk, serta karcis lainnya berkenaan dengan fasilitas di area wisata.

5. Adanya kerjasama antara dinas pariwisata kabupaten Garut dan pihak pengelola wisata dengan biro perjalanan (travel), hotel, dan UMKM untuk mengembangkan destinasi wisata kabupaten garut yang solid, berkelanjutan, dan terintegrasi sehingga branding garut sebagai destinasi wisata semakin massif dan gencar meskipun di masa pandemi.

\section{REFERENSI}

[1] Arjana, I. G. (2015). Geografi Pariwisata dan Ekonomi Kreatif. Jakarta: PT. Raja Grafindo Persada.

[2] Clifton, E. M. (2000). The Future of Brands: TwentyFive Visions, ed. New York: New York University Press.

[3] Duncan, T. (2005). Principle Of Advertising and IMC, International Edition, Edisi Kedua. New York: McGrawHill.

[4] Gamal, S. (2002). Dasar-Dasar Pariwisata. Yogyakarta: Penerbit Andi.

[5] Hadi, G. S. (2017). Pengaruh Citra Merek dan Kualitas Produk Terhadap Keputusan Pembelian Honda Brio Pada Konsumen Honda Semarang Center. Jurnal Ilmu Administrasi Bisnis Undip.

[6] Kotler, K. L. (2009). Manajemen Pemasaran Edisi 13 Jilid I trans. oleh Bob Sabran. Jakarta: Airlangga.

[7] Landa, R. (2006). Designing Brand Experiences. Thomson Delmar Learning.
[8] Masruroh. (2018). Analisis Branding Dalam Upaya Pengembangan Destinasi Wisata Religi Sunan Drajat. Pasca Sarjana UIN Surabaya (digilib.uinsby.ac.id).

[9] nasional.kompas.com. (2020, April 10). jubirpemerintah-penerapan-physical-distancing-

diperkuat-melalui-kebijakan. Jakarta, Indonesia.

[10] Nazir, M. (1998). Metode Penelitian, cet. III. Jakarta: Ghalia Indonesia.

[11] Nyoman, S. P. (2003). Ilmu Pariwisata Sebuah Pengantar Perdana. Jakarta: Gramedia Pustaka Utama.

[12] Prayudi. (2012). Public Relations Stratejik. Yogyakarta: CV Pandan Mas.

[13] Spillane, J. (1987). Pariwisata Indonesia Sejarah Dan Prospeknya. Yogyakarta: Kanisius.

[14] Suharsimi, A. (2006). Prosedur Penelitian Suatu Pendekatan Praktik. Jakarta: Rineka Cipta.

[15] Sunaryo, B. (2013). Kebijakan Pembangunan Destinasi Pariwisata Konsep dan Aplikasinya Di Indonesia. Yogyakarta: Gava Media.

[16] Susanto, H. d. (2004). Power Branding: Membangun Merek Unggul dan Organisasi Pendukungnya. Jakarta: PT Mizan Republika.

[17] tirto.id. (2020, Juni 5). menuju-new-normalkasus-baru-harian-indonesia-masih-fluktuatif. Jakarta, Indonesia.

[18] Tjiptono, F. (2005). Pemasaran Jasa, edisi pertama. Yogyakarta: Bayu Media Publishing.

[19] Wardana. (2017). Potensi Dan Strategi Pengembangan Pariwisata Di Kabupaten Pesisir Barat. digilib.unila.ac.id.

[20] Wardiyanta. (2006). Metode Penelitian Pariwisata. Yogyakarta: CV Andi Offset.

[21] Wibowo, A. S. (2016). . Analisis Potensi Pengembangan Objek Wisata Alam Kabupaten Kolaka Provinsi Sulawesi Tenggara. Fakultas Geografi UMS (ums.ac.id).

[22] Yoeti, O. (2008). Anatomi Pariwisata. Bandung: Angkasa.

[23] Yoeti, O. (2008). Ekonomi Pariwisata: Introduksi, Informasi, dan Implementasi. Jakarta: Kompas. 